\title{
Supplementation of a restricted maternal diet with protein or carbohydrate alone prevents a reduction in fetal muscle fibre number in the guinea-pig
}

\author{
BY CATHERINE M. DWYER AND NEIL C. STICKLAND \\ Department of Veterinary Basic Sciences, The Royal Veterinary College, Royal College Street, \\ London NWI OTU
}

(Received 24 April 1993 -Revised 25 October 1993 -Accepted 3 December 1993)

\begin{abstract}
A $60 \%$ reduction in maternal feed intake is known to cause a reduction of approximately $20 \%$ in biceps brachii fibre number in the guinea-pig fetus. This investigation was designed to isolate the dietary component responsible by reducing all dietary components to $60 \%$ of the ad lib. level and supplementing the protein, carbohydrate or fat component to the level of the ad lib. intake. Fetal muscles were examined at $50 \mathrm{~d}$ gestation to determine numbers of primary and secondary fibres, and at term to determine total fibre number. Fetal and neonatal weights were reduced in all restricted groups $(P<0.05)$ when compared with ad lib. controls. At term this reduction was significantly less $(P<0.05)$ in the protein-supplemented group $(20 \%)$ than in the $60 \%$-restricted and fat-supplemented groups $(43 \%)$ and the carbohydratesupplemented group (34\%). Biceps brachii fibre numbers were reduced in the $60 \%$-restricted and fatsupplemented groups by 14-16\%, but fibre numbers were similar in control, protein-supplemented and carbohydrate-supplemented groups. Any reduction in fibre number was in the secondary fibre component of total fibre number. Therefore, biceps brachii fibre numbers were reduced only when maternal diets were deficient in both protein and carbohydrate.
\end{abstract}

Protein: Carbohydrate: Malnutrition: Fetal myofibre development: Guinea-pig

A $60 \%$ reduction in maternal feed intake is known to cause a reduction of approximately $20 \%$ in muscle fibre number in fast muscles (Ward \& Stickland, 1991; Dwyer \& Stickland, 1992). This reduction is in the secondary fibre component of total fibre number (Ward \& Stickland, 1991). Secondary myotubes form as the second generation of muscle fibres, using the primary fibres as a framework on which to develop, and are considered more labile to nutritional influence than primaries (Handel \& Stickland, 1987). The purpose of the present study was to determine which component of the maternal diet is most important in affecting the development of muscle fibre numbers.

Severe restriction of the protein component of the maternal diet (to $5 \mathrm{~g} / \mathrm{kg}$ ) in pigs results in a reduction of fetal weights, piglet birth weights, weaning weights and postnatal weight gains (Pond et al. 1968, 1987, 1991; Atinmo et al. 1974) and this stunting seems to be permanent (Pond \& Wu, 1981; Pond et al. 1990). In the rat severe protein restriction caused smaller carcase and organ weights in late gestation fetuses (Zeman \& Stanbrough, 1969). Mild protein restriction, however, has no effect (Pond, 1973). Energy restriction alone, with normal levels of protein, causes a greater reduction in fetal rat body weight than protein restriction alone (Anugwa \& Pond, 1989), although this is not consistently the case in the pig (Pond et al. 1987). When non-protein energy restriction causes a reduction in piglet birth weight, this is associated with a low postnatal growth rate (Pond et al. 1987).

These findings, however, do not provide much information about the effect of these diets on the muscle cellularity of the developing fetuses. The effects of protein or carbohydrate 
restriction in postnatal rats and children suggest that a low-protein diet leads to a reduced protein synthetic capability (Young \& Alexis, 1968), therefore affecting cellular hypertrophy. A low-carbohydrate diet, however, causes reduced DNA levels but almost normal protein:DNA values (Cheek \& Hill, 1970; Winick, 1970), therefore affecting hyperplasia of cells.

The present hypothesis was that the carbohydrate portion of the diet would affect the hyperplastic phase and, hence, myofibre number; the protein portion would affect only the hypertrophic phase, and not myofibre number. In the present experiment the diets were designed to supplement the individual component under study to ad lib. levels whilst all other nutritional components were reduced to $60 \%$ of an ad lib. intake. It should be emphasized, therefore, that supplemented dietary components were high only in relation to the other restricted components and did not exceed the levels eaten by the control animals.

\section{MATERIALS AND METHODS}

This project involved thirty-one pregnant Dunkin-Hartley guinea-pigs obtained from Bantam and Kingman Ltd (Aldbrough, Humb.). Guinea-pigs were in their second parity and weighed between 700 and $900 \mathrm{~g}$ at the start of the experiment. On day 2 of gestation females were housed individually in plastic cages and assigned to a nutritional treatment. Diets were based on SG1 pellets (Grain Harvesters, Wingham, Kent) which provide $(\mathrm{g} / \mathrm{kg})$ : protein 190 , starch and sugars $232 \cdot 5$, oil $42 \cdot 5$, fibre $112 \cdot 5$, digestible energy $9 \cdot 60 \mathrm{MJ}$. Three test diets were formulated which were designed to provide control levels of the component under study and $60 \%$ of ad lib. (negative control) levels of all other components (Table 1). The compositions of these diets were as follows $(\mathrm{g} / \mathrm{kg}): \mathbf{R}+\mathbf{P}$, protein 273 , starch and sugars $232 \cdot 5$, oil $42 \cdot 5 ; R+C$, protein 190 , starch and sugars 335 , oil $42 \cdot 5 ; R+F$, protein 190 , starch and sugars $232 \cdot 5$, oil 91 .

All diets were enriched with vitamin C. Pregnant guinea-pigs were randomly assigned to treatments as follows: (1) Controls, ad lib. access to SG1 pellets, $n 6$; (2) 40R, pair-fed with SG1 pellets at $60 \%$ of ad lib. intake, $n 6$; (3) $\mathrm{R}+\mathrm{P}$, protein supplemented, $n 7$; (4) $\mathrm{R}+\mathrm{C}$, carbohydrate supplemented, $n 6$; (5) $\mathrm{R}+\mathrm{F}$, fat supplemented, $n 6$.

All animals were given unlimited access to clean, fresh drinking water containing vitamin E (30 mg/1; Roche Products Ltd, Welwyn Garden City, Herts.) since they were not allowed access to hay for the duration of the experiment.

Three randomly selected pregnant animals from each nutritional group were killed at $50 \mathrm{~d}$ gestation by an intraperitoneal injection of sodium pentabarbitone $(1 \mathrm{ml} / \mathrm{kg}$ body weight; Euthesate; Willows Francis Veterinary, a division of A. H. Robins, Crawley, West Sussex), and the remainder were allowed to litter and neonates were killed at term. Stillborn animals or pups which died within $24 \mathrm{~h}$ of birth were counted and weighed. Muscles were not always available from these animals, therefore, for consistency, muscles were analysed only from those animals which were alive at the time of sampling. Biceps brachii muscles were removed from all fetuses and neonates $(n 99)$, mounted on cork chucks and rapidly frozen in hexane cooled in liquid $\mathrm{N}_{2}$. Whole muscle transverse sections $(10 \mu \mathrm{m})$ were cut at $-25^{\circ}$ in a cryostat and stained for myosin ATPase $(E C$ 3.6.1 .32) activity after the method of Guth \& Samaha (1970). At $50 \mathrm{~d}$ gestation all biceps muscle fibres are present but it is still possible to determine which fibres developed as primary and secondary fibres on the basis of their ATPase staining pattern (Ward \& Stickland, 1991). Muscles from fetuses ( $n$ 57) were used to determine values for secondary:primary (S:P) fibres, and total fibre numbers. Neonates provided information about growth rate throughout gestation and muscles from neonates ( $n$ 42) were used to determine total myofibre numbers only, since cell lineages could no longer be distinguished at this age. All fibres were counted blind to 
Table 1. Example of the composition of diets eaten by different dietary groups, matched to a control animal eating $50 \mathrm{~g}$ feed ad lib.*

\begin{tabular}{lccccc}
\hline Dietary group & $\begin{array}{c}\text { Total feed } \\
(\mathrm{g} / \mathrm{d})\end{array}$ & $\begin{array}{c}\text { Protein } \\
(\mathrm{g})\end{array}$ & $\begin{array}{c}\text { Carbohydrate } \\
(\mathrm{g})\end{array}$ & $\begin{array}{c}\text { Fat } \\
(\mathrm{g})\end{array}$ & $\begin{array}{c}\text { Total ME } \\
(\mathrm{KJ})\end{array}$ \\
\hline Control $(n 6)$ & 50 & $9 \cdot 5$ & 11.63 & $2 \cdot 13$ & 477.5 \\
40R $(n 6)$ & 30 & $5 \cdot 7$ & 6.98 & 1.28 & 286.5 \\
R+P $(n 7)$ & 33.8 & 9.23 & 6.98 & 1.28 & 363.2 \\
R+C $(n 6)$ & 34.7 & $5 \cdot 7$ & 11.52 & 1.28 & 358.8 \\
R+F $(n 6)$ & 30.9 & $5 \cdot 7$ & 6.98 & 2.90 & 345.4 \\
\hline
\end{tabular}

ME, metabolizable energy; Control, ad. lib. access to SG1 pellets (Grain Harvesters, Wingham, Kent).

$40 \mathrm{R}$, pair-fed with $\mathrm{SG} 1$ pellets at $60 \%$ of ad lib. intake; $R+P$, protein-supplemented; $R+C$, carbohydratesupplemented; $\mathbf{R}+\mathbf{F}$, fat-supplemented.

* For details of diets, see p. 174.

diet groups using a Seescan Image Analysis system (Seescan Plc, Cambridge). Nutritional groups were compared using Newman-Keul ANOVA statistics.

\section{RESULTS}

\section{Maternal and fetal weight}

The effect of nutritional treatments on maternal and fetal weight gain is shown in Table 2 . At both $50 \mathrm{~d}$ gestation and term, control dams tended to gain more weight than any restricted group. Variations between individuals were, however, quite large. By term only the $40 R$ group and the $R+C$ groups showed a mean net weight loss when the influence of conceptus weight was removed $(-23$ and $-3 \mathrm{~g}$ respectively). This was significantly different from controls only in the 40R group. Fetal and placental weights were reduced by undernutrition in all restricted groups. The greatest reductions were seen in the $40 \mathrm{R}$ and $\mathrm{R}+\mathrm{F}$ groups $(33 \%)$ and the least in the $\mathrm{R}+\mathrm{P}$ group $(16 \%)$. By birth the $\mathrm{R}+\mathrm{P}$ group was intermediate between the control group and the remaining restricted groups. Neonatal mortalities also followed the same pattern and were restricted to the smallest neonates in each group; mean body weight of neonatal mortalities was $45 \cdot 28 \mathrm{~g}$ (range 29.7-52.5 g, $n$ 16).

\section{Fibre numbers}

Biceps brachii primary fibre number and mean $\mathrm{S}: \mathrm{P}$ ratio were determined from $50 \mathrm{~d}$ fetal muscles and are shown in Fig. 1 $(a$ and $b)$. Total muscle fibre numbers were counted in both $50 \mathrm{~d}$ fetuses and neonates. Results from fetuses and neonates could be combined since ANOVA tests revealed no significant difference in myofibre number between the two ages for any nutritional groups.

Primary fibre number did not differ between groups $(P>0 \cdot 05)$. However, mean $S: P$ ratio was similar for control, $R+P$ and $R+C$ groups and significantly greater than those for $40 R$ and $\mathrm{R}+\mathrm{F}$ groups $(P<0.05)$ by approximately $13.5 \%$. Combined total fibre number data (Fig. 1(c)) demonstrate a similar pattern to that of mean $\mathrm{S}: \mathrm{P}$ ratio, with total fibre number being reduced by $14-16 \%$ in the $40 \mathrm{R}$ and $\mathrm{R}+\mathrm{F}$ groups $(P<0.05)$.

\section{DISCUSSION}

In the present study it has been shown that a restricted maternal diet supplemented with either protein or carbohydrate was sufficient to maintain levels of secondary fibre hyperplasia (Fig. 1(b)) in the fetus at those of ad lib. controls, resulting in no reduction in biceps brachii fibre number (Fig. 1(c)). Primary fibre number is unaffected in any group 


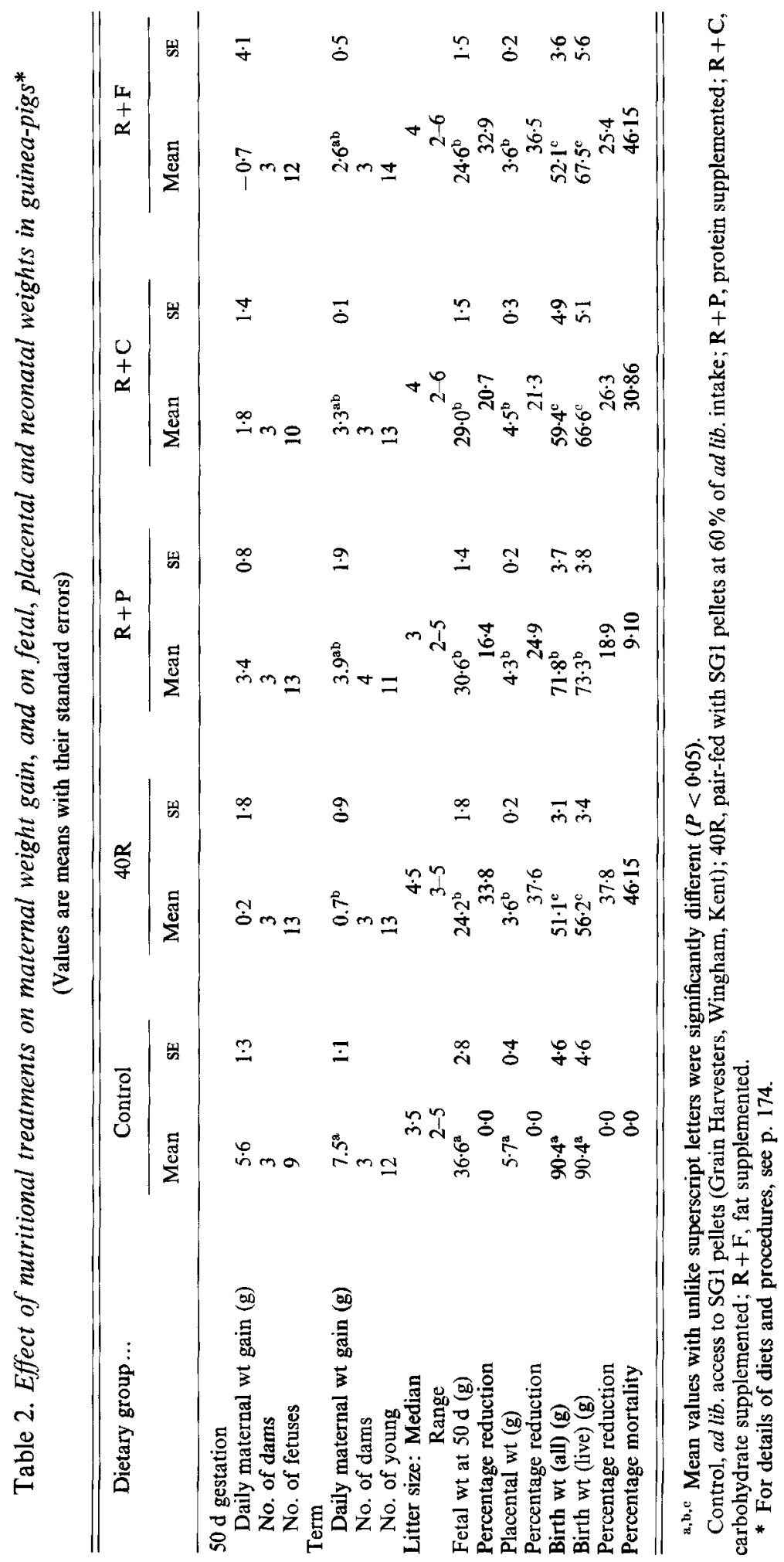




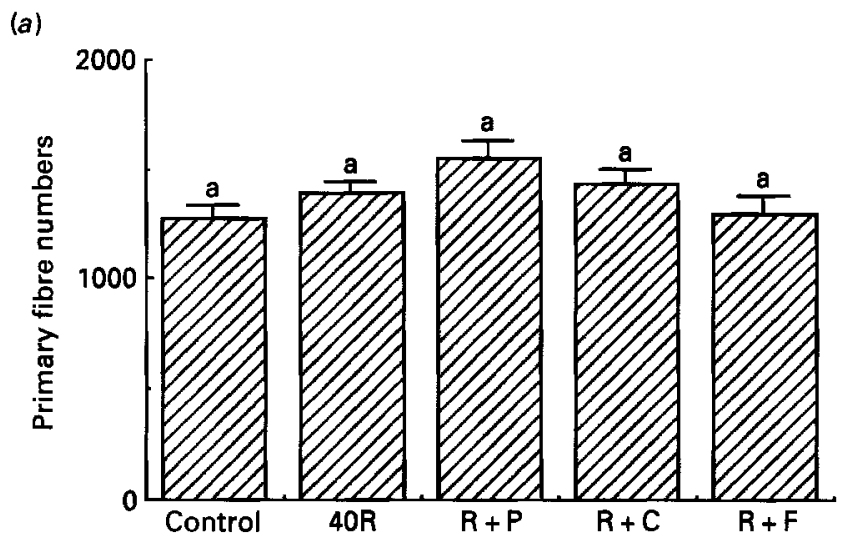

(b)
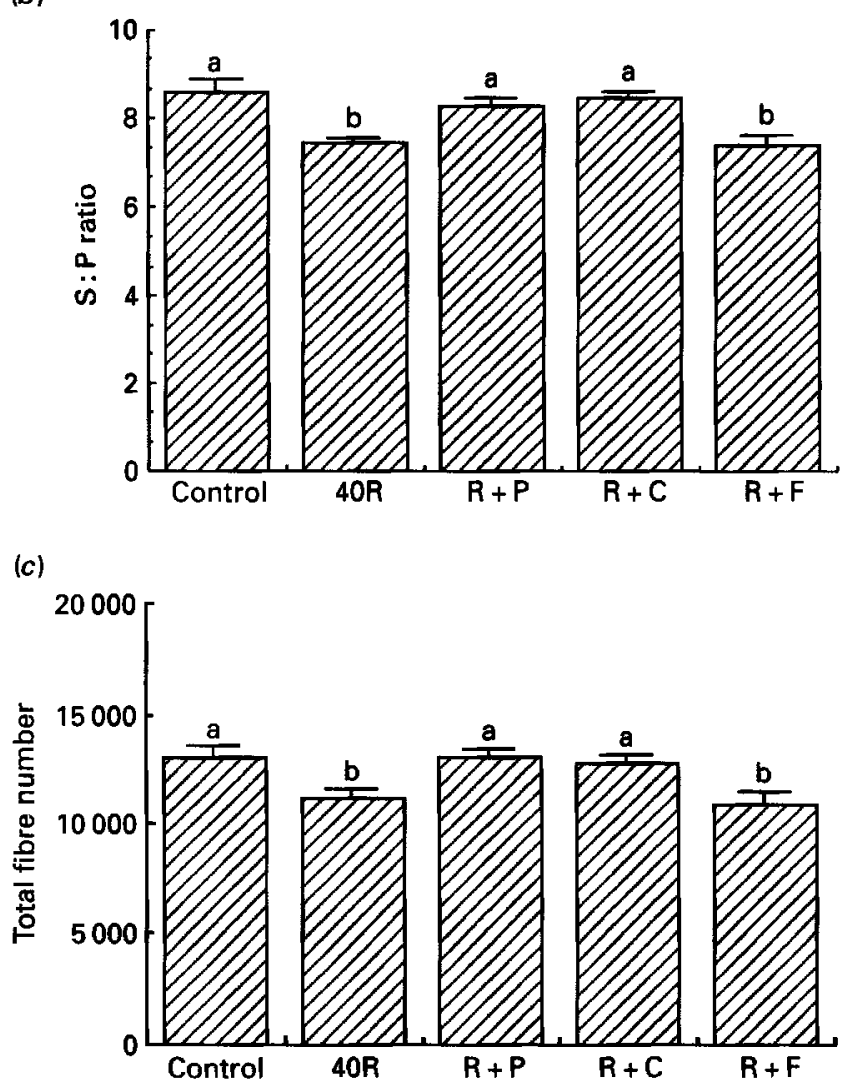

Fig. 1. Effect of nutritional treatments on mean biceps brachii myofibre numbers of guinea-pigs. (a) Primary fibre number, $(b)$ secondary: primary fibre number $(\mathbf{S}: \mathbf{P})$ ratio, and $(c)$ total myofibre number. Control, ad lib. access to SG1 pellets (Grain Harvesters, Wingham, Kent); 40R pair-fed with SG1 pellets at $60 \%$ of $a d$ lib. intake; $R+P$, protein supplemented; $\mathbf{R}+\mathbf{C}$, carbohydrate supplemented; $\mathbf{R}+\mathrm{F}$, fat supplemented; for details of diets and procedures, see p. 174 . Values are means with their standard errors represented by vertical bars. $a, b$, Mean values with unlike superscript letters were significantly different $(P<0.05)$. 
(Fig. 1(a)). However, none of the restricted diets, despite supplementation, was able to maintain fetal growth at the same rate as that seen in the control ad lib.-fed fetuses (Table 2 ). The birth weights of the $R+P$ protein-supplemented group were intermediate between those of the controls and other restricted groups. A high level of neonatal mortality was seen in the $40 \mathrm{R}$ ( $60 \%$-restricted) and $\mathrm{R}+\mathrm{F}$ (fat-supplemented) groups (Table 2), which was restricted to the smallest neonates. In general, it seems that a body weight of less than $50 \mathrm{~g}$ severely compromises the survival of the neonatal guinea-pig. A low birth weight tends to be associated with a reduced myofibre number (Handel \& Stickland, 1987), therefore, it is likely that these animals possessed a low fibre number. Thus, it is likely that the mean total fibre numbers of the $40 \mathrm{R}$ and $\mathrm{R}+\mathrm{F}$ groups are an overestimation of the true values. This would explain the reduction in fibre number of only $15 \%$ in these groups; reductions of $20 \%$ have been reported for this level of undernutrition (Ward \& Stickland, 1991; Dwyer $\&$ Stickland, 1992). However, these groups still had a significant reduction in fibre number (Fig. 1(c)). Furthermore, Fig. 1(b) demonstrates a significant reduction in secondary fibre proliferation in the $40 \mathrm{R}$ and $\mathrm{R}+\mathrm{F}$ groups only, determined at day 50 when all animals were included. Therefore, despite the $30 \%$ neonatal mortality in the $\mathrm{R}+\mathrm{C}$ group (Table 2), it is likely that the estimate for total myofibre number in this group is accurate and that fibre development in only the $40 \mathrm{R}$ and $\mathrm{R}+\mathrm{F}$ groups was affected by the nutritional treatment. The $9 \%$ neonatal mortality in the $R+P$ group is within the normal preweaning rate found in the guinea-pig (Sutherland \& Festing, 1986).

Placental weight was reduced also in all restricted fetuses at $50 \mathrm{~d}$ gestation (Table 2). This tended to be by a similar amount to fetal weight, except in the $R+P$ group where the decrease in placental weight seemed to exceed the decrease in fetal weight (respectively 25 and $16 \%$ ). This suggests that the placentas of protein-supplemented animals may be more efficient than those of other groups such that a heavier weight of fetus is supported per unit weight of placenta. Evidence from the pig suggests that maternal protein levels at the time of implantation may be important for the early establishment and growth of the placenta (Pond et al. 1969).

The important metabolic fuels in the fetus are glucose, amino acids, lactate and fatty acids (Jones \& Rolph, 1985). The fetus has high plasma and tissue levels of amino acids which are actively transported over the placenta from the maternal circulation (Jones \& Rolph, 1985). Amino acids may supply as much as $25 \%$ of the oxidative needs of the ovine fetus (Gresham et al. 1972). Thus, amino acids make an important contribution to fetal oxidative metabolism, and a decrease in glucose supply can cause a shift to increased amino acid degradation (Battaglia \& Meschia, 1978). This suggests that under conditions of low maternal plasma glucose there may be an increased fetal dependence on amino acids for oxidative metabolism at the expense of protein accretion. This may explain why $R+P$ fetuses were lighter than controls despite similar maternal protein intakes. $R+P$ fetuses were, however, significantly heavier than those of the other nutritional groups; thus, some of the extra protein must have been available to the fetuses for tissue accretion.

Amino acids may also act as precursors for gluconeogenesis. The placenta is incapable of gluconeogenesis (Bossi \& Greenberg, 1972); therefore, any newly synthesized glucose must be of fetal or maternal origin. The gluconeogenic enzymes are present in the guineapig liver from day 40 of gestation (Jones \& Ashton, 1976), but gluconeogenesis itself does not take place until late gestation (Jones \& Ashton, 1976; Faulkener \& Jones, 1976). Although there is some evidence that undernutrition may lead to an early initiation of gluconeogenesis (Jones, 1982), endogenous production of glucose by the fetus is unlikely to affect fibre numbers since the very early stages of gestation, the first trimester, appear to be the critical period for determination of fibre numbers (Dwyer et al. 1993). However, there may have been some maternal synthesis of glucose. 
Proteins may also be involved in the maintenance of fetal fibre numbers in an indirect manner by altering or maintaining the endocrine status of the fetus, particularly via insulin and the insulin-like growth factors (IGF). Plasma insulin is reduced in the porcine fetus when the sow is fed on a diet deficient in protein (Atinmo et al. 1976), and in children with kwashiorkor (Soliman et al. 1986). Secretion of insulin has been shown to be sensitive to dietary protein (Jepson et al. 1988). Protein restriction of pregnant rats causes a decrease in circulating somatomedin levels in both fetal and maternal serum (Pilistine et al. 1984). Protein restriction of young postnatal rats also causes a reduction in serum IGF-1 and liver and muscle IGF-1 mRNA (Moats-Staats et al. 1989; Yahya et al. 1990; Vandehaar et al. 1991). IGF-1 appears to be linearly related to protein levels when energy levels are kept constant (Dardevet et al. 1991). Therefore, IGF-1 levels appear to be maintained independently by carbohydrate and protein levels. Thus, both the levels of glucose and amino acids may act via an insulin pathway, involving insulin and the IGF, to affect fibre number.

The role of fats in fetal muscle development appear fairly minor since plasma levels of fatty acids in the fetus are usually low until late gestation (Jones \& Rolph, 1985). In addition, higher levels of fat in the maternal diet seemed ineffective at preventing low birth weight and postnatal mortality (Table 2 ).

In conclusion, the hypothesis that the carbohydrate portion of the diet would be sufficient to maintain control numbers of muscle fibres was confirmed. However, the protein portion of the maternal diet was also found to be equally effective. The extra protein in the diet may have been used as a supply of amino acids for oxidative metabolism, as precursors for gluconeogenesis, and/or may have played a role in the maintenance of fetal endocrinology, such that fibre number development was not impaired.

\section{This work was supported by the Agricultural and Food Research Council.}

\section{REFERENCES}

Anugwa, F. O. I. \& Pond, W. G. (1989). Reproduction and organ weights in rats fed high protein, restricted balanced diets or restricted nonprotein calories. Nutrition Reports International 40, 879-892.

Atinmo, T., Baldijao, C., Pond, W. G. \& Barnes, R. H. (1976). Maternal protein malnutrition during gestation alone and its effects on plasma insulin levels of the pregnant pig, its fetuses and the developing offspring. Journal of Nutrition 106, 1647-1653.

Battaglia, F. C. \& Meschia, G. (1978). Principle substrates of fetal metabolism. Physiological Reviews 58, $499-527$.

Bossi, E. \& Greenberg, R. E. (1972). Sources of blood glucose in the rat fetus. Pediatric Research 6, 765-772.

Cheek, D. B. \& Hill, D. E. (1970). Muscle and liver cell growth: role of hormones and nutritional factors. Federation Proceedings 29, 1503-1509.

Dardevet, D., Manini, M., Balage, M., Sornet, C. \& Grizard, J. (1991). Influence of low- and high-protein diets on insulin and IGF-1 binding to skeletal muscle and liver in the growing rat. British Journal of Nutrition 65 , 47-60.

Dwyer, C. M., Madgwick, A. J. A., Ward, S. S. \& Stickland, N.C. (1993). The effect of maternal undernutrition, imposed before or after the first trimester, on muscle fibre development in the guinea pig. Journal of Anatomy 183, 200 Abstr.

Dwyer, C. M. \& Stickland, N. C. (1992). Does the anatomical location of a muscle affect the influence of undernutrition on muscle fibre number? Journal of Anatomy 181, 373-376.

Faulkener, A. \& Jones, C. T. (1976). Metabolic concentrations in the liver of the adult and developing guinea pig and the control of glycolysis in vivo. Archives of Biochemistry and Biophysics 176, 171-180.

Gresham, E. L., James, E. J., Raye, J. R., Battaglia, F. C., Makowski, E. L. \& Meschia, G. (1972). Production and excretion of urea by the foetal lamb. Pediatric Research 50, 372-379.

Guth, L. \& Samaha, F. J. (1970). Research note: procedure for the histochemical demonstration of actomyosin ATPase. Experimental Neurology 28, 365-367.

Handel, S. E. \& Stickland, N. C. (1987). Muscle cellularity and birth weight. Animal Production 44, 311-317.

Jepson, M. M., Bates, P. C. \& Millward, D. J. (1988). The role of insulin and thyroid hormones in the regulation of muscle growth and protein turnover in response to dietary protein in the rat. British Journal of Nutrition 59 , 397-415. 
Jones, C. T. (1982). Comparative aspects of hepatic glucose metabolism during foetal development. Biochemical Society Transactions $9,375-376$.

Jones, C. T. \& Ashton, I. R. (1976). The appearance, properties and functions of gluconeogenic enzymes in the liver and kidney of the guinea pig during foetal and early neonatal development. Archives of Biochemistry and Biophysics 174, 506-522.

Jones, C. T. \& Rolph, T. P. (1985). Metabolism during foetal life: a functional assessment of metabolic development. Physiological Reviews 65, 357-430.

Moats-Staats, B. M., Brady, J. L., Underwood, L. E. \& D'Ercole, A. J. (1989). Dietary protein restriction in artificially reared neonatal rats causes a reduction in IGF-1 gene expression. Endocrinology 125, $2368-2375$.

Pilistine, S. J., Moses, A. C. \& Munro, H. N. (1984). Placental lactogen administration reverses the effect of a low protein diet on maternal and foetal serum somatomedin levels in the pregnant rat. Proceedings of the National Academy of Sciences, USA 81, 5853-5857.

Pond, W. G. (1973). Influence of maternal protein and energy nutrition during gestation on progeny performance in swine. Journal of Animal Science 36, 175-182.

Pond, W. G., Maurer, R. R. \& Klindt, J. (1991). Fetal organ response to maternal protein deprivation during pregnancy in swine. Journal of Nutrition 121, 504-509.

Pond, W. G., Strachan, D. N., Sinha, Y. N., Walker, E. F., Dunn, J. A. \& Barnes, R. H. (1969). Effect of protein deprivation of swine during all or part of gestation on birth weight, postnatal growth rate and nucleic acid content of brain and muscle of progeny. Journal of Nutrition 99, 61-67.

Pond, W. G., Wagner, W. C., Dunn, J. A. \& Walker, E. F. (1968). Reproduction and early post natal growth of progeny in swine fed a protein-free diet during gestation. Journal of Nutrition 94, 309-316.

Pond, W. G. \& Wu, J. F. (1981). Mature body size and life span of male and female progeny of primiparous rats fed a low protein or adequate diet throughout pregnancy. Journal of Nutrition 111, 1949-1954.

Pond, W. G., Yen, J.-T. \& Mersmann, H. J. (1987). Effect of severe dietary protein, non-protein calories or feed restriction during gestation on postnatal growth of progeny in swine. Growth 51, 355-371.

Pond, W. G., Yen, J.-T., Mersmann, H. J. \& Maurer, R. R. (1990). Reduced mature size in progeny of swine severely restricted in protein intake during pregnancy. Growth, Development and Aging 54, 77-84.

Soliman, A. T., Hassan Abd. el Hadi I., Aref, M. K., Hintz, R. L., Rosenfeld, F. G. \& Rogol, A. D. (1986). Serum IGF-I and IGF-II concentrations and growth hormone and insulin responses to arginine infusion in children with protein-energy malnutrition before and after nutritional rehabilitation. Pediatric Research 20, $1122-1130$.

Sutherland, S. D. \& Festing, M. F. W. (1986). The guinea pig. In The UFAW Handbook on the Care and Management of Laboratory Animals, pp. 393-410 [T. B. Poole, editor]. London: Longman Scientific \& Technical.

Vandehaar, M. J., Moats-Staats, B. M., Davenport, M. L., Walker, J. L., Ketelslegers, J.-M., Sharma, B. K. \& Underwood, L. E. (1991). Reduced serum concentrations of IGF-1 in protein-restricted growing rats are accompanied by reduced IGF-1 mRNA levels in liver and skeletal muscles. Journal of Endocrinology 130, 305-312.

Ward, S. S. \& Stickland, N. C. (1991). Why are fast and slow muscles differentially affected during prenatal undernutrition? Muscle and Nerve 14, 259-267.

Winick, M. (1970). Nutrition and nerve cell growth. Federation Proceedings 29, 1510-1515.

Yahya, Z. A. H., Bates, P. C. \& Millward, D. J. (1990). Responses to protein deficiency of plasma and tissue IGF1 levels and proteoglycan synthesis rates in rat skeletal muscle and bone. Journal of Endocrinology 127,497-503.

Young, V. R. \& Alexis, S. D. (1968). In vitro activity of ribosomes and RNA content of skeletal muscle in young rats fed adequate or low protein. Journal of Nutrition 96, 255-262.

Zeman, F. J. \& Stanbrough, E. C. (1969). Effect of maternal protein deficiency on cellular development in the foetal rat. Journal of Nutrition $99,274-282$. 